Ekuitas: Jurnal Pendidikan Ekonomi

Volume 9, Number 1, Tahun 2021, pp. 27-33

P-ISSN : 2354-6107E-ISSN : 2549-2292

DOI : $10.23887 /$ ekuitas.v9i1.27469

Open Access: https://ejournal.undiksha.ac.id/index.php/EKU

\title{
Menyelisik Strategi Pengelola LPD Desa Adat Pedawa dalam Menekan Non Performing Loan (NPL)
}

\author{
Luh Putu Novita Wahyuni ${ }^{*}$, Ni Wayan Yulianita Dewi ${ }^{2}$ \\ 1,2Universitas Pendidikan Ganesha, Singaraja-Indonesia
}

\author{
A R T I C L EI N F O \\ Article history: \\ Received July, 242020 \\ Received in revised form \\ June, 42021 \\ Accepted June, 72021 \\ Available online June, 28 \\ 2021 \\ Kata Kunci: \\ LPD, NPL, sanksi nunda \\ tetegenan. \\ Keywords: \\ $L P D, N P L$, nunda tetegenan \\ sanctions.
}

\begin{abstract}
A B S T R A K
Penelitian ini dilakukan untuk menyelisik strategi manajemen Lembaga Perkreditan Desa Desa Adat Pedawa dalam menekan Non Performing Loan. Metode penelitian yang digunakan dalam penelitian ini adalah metode kualitatif deskriptif. Data diperoleh melalui wawancara mendalam, observasi dan studi dokumen yang selanjutnya dianalisis dengan analysis interactive model dari Miles dan Huberman (1967). Hasil penelitian menunjukan bahwa permasalahan NPL yang terjadi pada LPD mengalami penurunan setelah diterapkannya sanksi nunda tetegenan yang merupakan tradisi kuno Desa Adat Pedawa. Nunda tetegenan terdiri dari 3 tingkat yaitu sanksi sosial, sanksi adat, dan sanksi saksi. Sanksi nunda tetegenan ini tidak melarang krama desa untuk menjalankan kewajibannya sebagai umat beragama untuk melaksanakan kegiatan yadnya, melainkan menunda hak krama untuk memperoleh saksi adat, menunda negen kenakenaan banten piodalan namun masih bisa mengaturkan banten dan menunda hak untuk memperoleh layanan dari Desa Adat.
\end{abstract}

\begin{abstract}
A B S T R A C T
This research was conducted to explore the management strategy of LPD in Pedawa Customary Village in suppressing NPLs. The research method applied in this research was descriptive qualitative method. Data were obtained through in-depth interviews, observation and study of documents which were then analyzed byanalysis interactive model from Milesand Huberman (1967). The results show that the occurrence of NPL problems in LPD decreases after the implementation of nunda tetegenan sanctions as an ancient tradition in Pedawa Customary Village. Nunda tetegenan consists of 3 levels, namely social sanctions, customary sanctions and witness sanctions. This nunda tetegenan sanction does not prohibit village manners from carrying out their obligations as religious people to carry out their yad activities, but rather delaying the right manners to acquire customary witnesses, postponing negen kena-kenaan banten piodalan but still being able to offer other offerings, and delaying the right to obtain services from Customary Villages .
\end{abstract}

Corresponding author.

E-mail : novitawahyuni54@gmail.com (Luh Putu Novita Wahyuni) 


\section{Pendahuluan}

Lembaga Perkreditan Desa yang selanjutnya disebut LPD adalah lembaga keuangan milik desa adat yang berkedudukan di wewidangan (wilayah) desa adat (Peraturan Daerah Provinsi Bali Nomor 3 Tahun 2017 tentang LPD). Menurut Sudiyani (2016), LPD merupakan salah satu subsistem lembaga keuangan milik desa adat yang kegiatannya bergerak di bidang perkreditan yaitu menghimpun dana (kredit pasif) dan menyalurkan dana (kredit aktif) dengan tingkat suku bunga tertentu. Non Performing Loan adalah suatu keadaan dimana pihak debitur tidak memiliki kemampuan untuk membayar kewajibannya kepada pemberi pinjaman (Iramanmi:2015). Pihak lembaga keuangan akan melakukan analisis kredit kepada nasabah, analisis tersebut terdiri dari character, capacity, capital, collateral, condition of economy yang dikenal dengan istilah 5C (Kasmir 2014 : 94). Namun, dalam penelitian yang dilakukan oleh Revi (2015) menjelaskan bahwa pada keadaan di lapangan, faktor intern yaitu kurangnya penerapan analisis kredit serta kesalahan dalam melakukan analisis kredit merupakan faktor dominan yang menyebabkan terjadinya permasalahan NPL.

Lembaga Perkreditan Desa Desa Adat Pedawa, Kecamatan Banjar, Kabupaten Buleleng merupakan LPD yang dipilih sebagai objek penelitian. Alasan dipilihya LPD Desa Adat Pedawa sebagai lokasi penelitian karena merupakan salah satu LPD yang berdiri di Desa Bali Aga. Desa Bali Aga atau Desa Bali Mula adalah desa yang penduduknya asli Bali serta mampu mempertahankan budaya dan tradisi nenek moyang hingga kini. Budaya dan tradisi kuno yang dimiliki oleh Desa Adat Pedawa menjadikan hubungan yang sangat erat dengan pengelolaan LPD, pada tahun 2015-2016 LPD mengalami permasalahan NPL yang tinggi yang juga mempengaruhi kinerja organisasi. Namun yang menarik adalah pengurus LPD mampu menyelesaikan permasalahan tersebut dengan menerapkan konsep budaya kuno yang memang melekat dalam tatanan kehidupan masyarakat Desa Adat Pedawa sebagai salah satu Desa Bali Aga. Keadaan tersebut mendorong pihak pengurus LPD serta desa adat untuk segera mengambil tindakan yang tegas demi keberlanjutan LPD kedepannya. Pada saat rapat bungan taun (rapat tahunan) 2016 yang dilaksanakan oleh pengurus Desa Adat Pedawa dan pengelola LPD menghasilkan keputusan yaitu menerapkan kembali budaya kuno Desa Bali Pedawa sebagai strategi untuk menangani permasalahan NPL. Keberhasilan manajemen LPD Desa Adat Pedawa bersama pengurus Desa Adat dalam menerapkan budaya kuno sebagai strategi untuk menangani NPL menyebabkan penurunan angka NPL pada tahun 2017 hingga tahun berikutnya.

\section{Metode}

Metode Kualitatif deskriptif dipilih dalam penelitian ini karena penelitian ini berfokus untuk menyelisik strategi manajemen LPD Desa Adat Pedawa dalam menekan permasalahan NPL sehingga diperlukan informasi dan data yang mendalam. Lokasi penelitian ini bertempat di Desa Pedawa, Kecamatan Banjar, Kabupaten Buleleng. Desa ini merupakan desa yang termasuk ke dalam bagian dari desa bali aga (desa bali mula) yang berada di Bali Utara yang mana kehidupan masyarakatnya hingga saat ini sangat kental akan budaya dan tradisi kuno dari turun temurun. Desa Pedawa juga memiliki lembaga keuangan yang berada di bawah naungan desa adat yaitu LPD. Pengeloaan LPD didasarkan pada awigawig (hukum adat) seperti pendirian LPD, mekanisme pemberian pinjaman, maupun sanksi terkait dengan kegiatan operasional di dalamnya. Dipilihnya Desa Adat Pedawa sebagai lokasi penelitian karena LPD Desa Adat Pedawa memiliki keunikan dalam upaya menekan angka NPL di LPD Desa Adat Pedawa yaitu dengan menerapkan kembali tradisi budaya kuno yang telah diatur dalam awig-awig (hukum adat).

Metode yang digunakan dalam penelitian ini dalam mengumpulkan data adalah metode wawancara, metode observasi dan dokumentasi. Informan dalam penelitian ini yaitu Kelian Adat (ketua lingkungan desa adat) Desa Pedawa dan ketua LPD Desa Adat Pedawa. Alasan dipilihnya beberapa informan tersebut yaitu karena kelian adat merupakan juru kunci desa adat setempat sehingga untuk memperoleh informasi yang mendalam terkait dengan pengelolaan LPD serta sanksi sosial di dalam awigawig desa adat. Ketua LPD memiliki peran penting dalam memberikan informasi yang mendalam terkait dengan pengelolaan kredit, upaya yang dilakukan oleh pihak manajemen, serta data kuantitatif yang menunjang penelitian ini. Penelitian ini memfokuskan untuk menyelisik strategi manajemen LPD Desa Adat Pedawa dalam menekan permasalahan NPL sehingga yang menjadi objek dalam penelitian ini yaitu strategi manajemen LPD, sanksi adat, serta prosedur penyaluran kredit yang diatur dalamawig-awig. Dokumentasi yang digunakan dalam penelitian ini adalah berupa laporan keuangan LPD Desa Adat Pedawa, laporan perkembangan pinjaman periode 2015-2019, SOP pemberian pinjaman, serta awig-awig (hukum adat) yang dimiliki oleh Desa Adat Pedawa. Teknik analisis data yangdigunakan dalampenelitianini adalah analysis interactive model dari Miles dan Huberman (1967), analisis data 
terdiri atas beberapa tahapan yaitu: pengumpulan data (data collection), reduksi data (data reduction), penyajian data (data display), dan penarikan kesimpulan atau verifikasi (conclutions).

\section{Hasil Dan Pembahasan Lembaga Perkreditan Desa (LPD) Desa Adat Pedawa}

Lembaga Perkreditan Desa Desa Adat Pedawa didirikan sekitar tahun 1990-an, awal didirikannya LPD Desa Adat Pedawa yaitu karena adanya instruksi oleh Gubernur yang mengharuskan setiap desa adat wajib mendirikan sebuah lembaga keuangan yang hanya dimiliki dan dikelola langsung oleh setiap desa adat yang ada di Bali. Keadaan ekonomi masyarakat di Desa Pedawa pada tahun 1990 sangat lemah sehingga banyak krama desa yang mengalami kesulitan dalam mencari bantuan dana untuk mengembangkan usaha maupun untuk memenuhi kebutuhan sehari-hari. Melihat kondisi tersebut akhirnya didirikanlah LPD Desa Adat Pedawa untuk mengelola kekayaan yang dimiliki oleh desa adat Pedawa serta meningkatkan perekonomian krama desa adat. Lembaga Perkreditan Desa Desa Adat Pedawa adalah salah satu LPD yang masih menggunakan awig-awig (aturan/hukum adat) sebagai pedoman dalam menjalankan kegiatan operasionalnya dengan tujuan yaitu agar mampu mengikat krama yang membutuhkan bantuan dana (pinjaman) kepada pihak LPD agar tidak melanggar aturan yang telah disepakati.

\section{Struktur Organisasi LPD Desa Adat Pedawa}

Pada umumnya, setiap organisasi memiliki struktur organisasi di dalamnya. Menurut Haisbuan (2010) struktur organisasi adalah suatu gambaran yang menggambarkan tipe organisasi, dan jenis wewenang pejabat, bidang dan hubungan pekerjaan, garis perintah dan tanggung jawab, rentang kendali dan sistem pimpinan organisasi. Lembaga Perkreditan Desa Desa Adat Desa Adat Pedawa dalam melaksanakan segala aktivitas organisasinya memiliki pembagian tugas tersendiri bagi para anggotanya. Dalam kegiatan operasionalnya, LPD Desa Adat Pedawa memiliki struktur organisasi dengan rincian tugas dan wewenangnya sebagai berikut:

1. Kepala mempunyai tugas:

A. Mengkoordinir pengelolan LPD

B. Bertanggung jawab kedalam dan keluar yakni kedalam bertanggung jawab atas perkembangan pengelolaan LPD dan keluar bertanggung jawab mewakili LPD baik di dalam maupun diluar pengadilan

2. Tata Usaha mempunyai tugas menyelenggarakan administrasi umum

3. Bendahara mempunyai tugas:

A. Melaksanakan transaksi keuangan

B. Membuat berita acara uang kas

Pembagian tugas, wewenang maupun tanggung jawab yang dilaksanakan oleh pihak pengelola LPD Desa Adat Pedawa dilaksanakan dalam rangka mencapai tujuan dari LPD itu sendiri yaitu membangun dan meningkatkan ekonomi krama desa adat. Hal ini diungkapkan dalam kutipan wawancara pada tanggal 7 Februari 2020 dengan Bapak Suarta (selaku Kepala LPD Desa Adat Pedawa) :

“....Pemisahan tugas dan wewenang ini membuat semua pihak lebih berfokus pada pekerjaanya masing-masing serta memperkuat pengawasan. Nike semua tidak terlepas dari awig-awig (aturan atau hukum adat) yang mengikatnya. Berfungsinya struktur organisasi dengan baik akan mempengaruhi kinerja setiap individu, begitupula dengan jenis permasalahan yang ada dan cara mengatasinya"

\section{Strategi Manajemen LPD Desa Adat Pedawa Dalam Menekan NPL}

Penyaluran dana pada setiap LPD di Bali berbeda prosedurnya, hal tersebut didasarkan pada awigawig yang dimiliki oleh setiap desa adat berbeda. Awig-awig merupakan aturan/hukum yang digunakan sebagai pedoman dalam melaksanakan kegiatan operasional pada LPD dengan maksud dan tujuan agar mampu mengikat krama desa adat yang membutuhkan dana untuk tidak melanggar aturan yang telah disepakati sebelumnya. LPD Desa Adat Pedawa yang merupakan lokasi penelitian dan hingga saat ini masih menggunakan awig-awig sebagai dasar dalam menjalankan kegiatan operasionalnya. Pemanfaatan awig-awig pada LPD Desa Adat Pedawa bertujuan untuk meningkatkan kualitas pengendalian internal 
sebagai salah satu upaya untuk menekan angka NPL. Hal tersebut diungkapkan saat kegiatan wawancara dengan Bapak Sudiastika (45 tahun) selaku kelian adat Desa Adat Pedawa, pada tanggal 8 Februari 2020.

“....LPD Desa Adat Pedawa hingga saat ini menggunakan awig-awig desa adat. Pendirian LPD, kepengurusan, tugas dan wewenang, prosedur mengajukan pinjaman serta sanksi yang harus diterima apabila debitur tidak mampu melunasi hutangnya diatur jelas dalam awig-awig khusus."

Prosedur pengajuan pinjaman pada LPD Desa Adat Pedawa di dalam awig-awig sedikit mengalami perubahan terkait dengan syarat bagi krama desa yang akan mengajukan pinjaman, krama desa yang memenuhi syarat untuk mengajukan permohonan pinjaman langsung mengumpulkan berkas lengkap yang sudah disiapkan yang selanjutnya akan diajukan kembali kepada panuriksa (pengawas). Hal ini didasarkan pada hasil wawancara dengan Bapak Sudiastika (selaku kelian adat desa pedawa) :

"Yening prosedur permohonan pengajuan kredit nike dari berdirinya LPD hingga saat ini mengalami perubahan sedikit pada syarat pengajuannya nike diperketat lagi dan nike sampun dibahas pada saat rapat bungan taun (rapat tahunan). Jadi untuk krama desa yang akan mengajukan permohonan pinjaman nanti akan melampirkan surat permohonan sendiri kemudian jika berkas yang diajukan sudah sesuai dengan syarat maka malih dibuatkan surat permohonan di LPD yang nanti akan ditunjukan kepada panuriksa (pengawas), kalau disetujui baru kemudian akan diproses lebih lanjut."

Pengajuan kredit yang telah disepakati hingga kini juga sesuai dengan prosedur yang benar. Namun, pada tahun 2015 LPD Desa Adat Pedawa mengalami permasalahan NPL yang cukup tinggi. Angka NPL juga mengalami peningkatan pada tahun berikutnya. Permasalahan ini memang pernah terjadi sebelumnya, namun dengan persentase kredit macet yang kecil. Peningkatan angka NPL di LPD Desa Adat Pedawa terjadi pada jenis kredit musiman dimana krama desa yang meminjam dana tidak memiliki kemampuan dalam melunasi kewajibannya kepada pihak LPD. Kredit musiman adalah jenis kredit yang ditawarkan oleh LPD kepada krama desa yang memiliki penghasilan yang didominasi dari hasil panen. Ketidakmampuan krama desa untuk mengembalikan pinjamannya disebabkan karena pada tahun 20152016 pohon cengkeh dan kopi yang seharusnya sudah memasuki musim panen tidak berbuah, hal tersebut dikarenakan perubahan cuaca yang ekstrim serta beberapa alasan lainnya. Kondisi tersebut diungkapkan saat kegiatan wawancara dengan Bapak Ketut Suarta (selaku kepala LPD Desa Adat Pedawa) pada tanggal 7 februari 2020 :

"Permasalahan yang dihadapi oleh LPD Desa Adat Pedawa adalah kredit macet, menjadi permasalahan terbesar sepanjang sejarah sejak didirkannya LPD karena persentase kredit macet nike sangat tinggi, semua pihak juga merasa kawatir terutama manejemen LPD. Tepat pada tahun 2015 kami melakukan pendekatan kepada krama desa yang tercatat tidak memiliki hutang agar kami tahu alasannya napi manten, karena kalau dari kami selaku pihak internalnya sudah melaksanakan kegiatan operasional sesuai standar operasional prosedur (SOP) serta tetap berpedoman pada aturan pada awig-awig. Alasannya beragam namun yang lebih banyak tercatat yaitu krama yang menggunakan kredit musiman ya karena memang pada tahun 2015-2016 nike gagal panen cengkeh dan kopi.

Permasalahan NPL yang tinggi yang dihadapi oleh LPD Desa Adat Pedawa yaitu pada tahun 2016. Kondisi tersebut nantinya akan menyebabkan kerugian bagi pihak LPD karena jika angka NPL tinggi akan menyebabkan pertumbuhan LPD menjadi tidak baik. Pada pelaksanaan rapat bungan taun yang rutin dilaksanakan pada setiap tahunnya menghasilkan keputusan untuk memberikan sanksi berupa pembebanan bunga tambahan bagi krama desa yang tidak memiliki kemampuan untuk melunasi hutangnya setelah memperoleh surat peringatan ke-3. Hal ini diungkapkan saat kegiatan wawancara dengan Bapak Suarta (selaku kepala LPD Desa Adat Pedawa) pada tanggal 8 Februari 2020 :

“....Tahun 2016 nike tahun tertinggi permasalahan NPL, pemberian surat peringatan pertama hingga ketiga sudah dijalankan namun persentase NPL mengalami kenaikan hingga akhirnya pada kegiatan rapat bungan taun kami jadikan permasalahan niki sebagai agenda utama hingga akhirnya menghasilkan keputusan terkait dengan sanksi. Sanksi yang akan dikenakan berupa pembebanan bunga tambahan, sanksi ini bukan memberatkan krama namun mendorong krama yang memiliki hutang agar berupaya untuk melunasi hutangnya sesuai jangka waktu yang telah disepakati sebelumnya."

Keputusan untuk menerapkan sanksi berupa pembebanan bunga nyatanya tidak membawa perubahan angka NPL, keadaan tersebut mendorong manajemen LPD harus meminjam dana dari Bank demi keberlanjutan LPD Desa Adat Pedawa kedepannya. Pada akhir tahun 2017, prajuru desa adat (pengurus desa adat) Pedawa kembali melaksanakan rapat bungan taun dengan agenda utama yaitu permasalahan NPL pada LPD Desa Adat Pedawa.Strategi yang diputuskan untuk diterapkan oleh manajemen LPD Desa Adat Pedawa merupakan bagian dari budaya kuno Desa Adat Pedawa. Manajemen LPD serta panuriksa diharapkan dapat menjalankan strategi tersebut sebagai upaya untuk menekan angka NPL.

Strategi tersebut dahulu dikenal dengan istilah nunda tetegenan. Nunda artinya menunda dan tetegenan artinya tanggungjawab yang dipikul. Jadi nunda tetegenan merupakan penundaan dalam 
memperoleh hak untuk ikut memikul tanggungjawab sosial sebagai umat beragama. Nunda tetegenan terdiri dari 3 tingkat yaitu sanksi sosial, sanksi adat, dan sanksi saksi. Sanksi sosial dalam hal ini merupakan bentuk sanksi kepada krama desa yang tidak memiliki kemampuan untuk membayar kewajibannya kepada LPD dan sudah mendapatkan surat peringatan 1. Sanksi sosial yang diberikan murni diperoleh langsung dari krama desa karena pada saat rapat adat dan rapat bungan taun untuk krama yang bermasalah langsung diberitahukan oleh panuriksa sehingga akan tumbuh rasa malu. Sanksi adat merupakan bentuk sanksi yang diberikan langsung oleh adat berupa larangan untuk mengikuti seluruh kegiatan di banjar adat yang diberikan kepada krama desa yang tidak memiliki kemampuan untuk membayar kewajibannya kepada LPD dan sudah mendapatkan surat peringatan 2. Sanksi saksi merupakan bentuk sanksi yang diberikan oleh adat berupa penundaan diterimanya hak saksi untuk krama yang bermasalah dalam semua kegiatan atau upacara seperti dalam upacara keagamaan manusa yadnya (persembahan yang tulus iklas kepada sesama manusia) acara telubulanan (tigabulanan) atau pawiwahan (pernikahan) atau kematian maka keluarga inti dari krama tersebut tidak memperoleh saksi prajuru desa adat untuk melangsungkan acaranya.

Sanksi nunda tetegenan ini berupa ditundanya kewajiban krama untuk memikul tetegenan berupa kena-kenaan banten dalam upacara yadnya (upacara keagamaan dalam agama hindu) yang tidak memiliki kemampuan dan kemauan untuk melunasi kewajibannya untuk ikut dalam setiap upacara keagamaan seperti dalam piodalan alit (upacara keagamaan kecil), piodalan ageng (upacara keagamaan besar) serta pada saat upacara sabha malunin (upacara persembahan kepada para Dewa, utamanya Dewa Utama atau yang disebut Dewa Kaki Dewaci) ditunda untuk mengeluarkan kena-kenaan banten (kesempatan untuk menghaturkan sarana upacara ditunda). Strategi yang dijalankan oleh manajemen LPD dan pengurus desa adat dalam menekan NPL sudah disepakati sebelumnya oleh krama desa adat karena pertama dengan menunda hak krama desa dalam mengahaturkan yadnya (korban suci yang tulus iklas dalam ajaran agama Hindu) yang berupa kena-kenaan banten piodalan maka krama desa yang tidak memiliki kemauan dan kemampuan untuk membayar kewajibannya akan merasa gundah, merasa bersalah dan malu sehingga selanjutnya akan berusaha untuk membayar kewajibannya. Kedua, sanksi saksi yang diberikan kepada krama desa berupa tidak diperolehnya hak saksi yaitu dari pihak pengurus desa adat untuk menjalankan segala upacara yadnya maka akan menyebabkan upacara yadnya tersebut tidak lancar karena tidak disaksikan langsung oleh prajuru desa adat. Sanksi nunda tetegenan dilaksanakan kembali setelah adanya pertimbangan hingga diperoleh kesepakatan dari semua pihak karena hanya berupa penundaan bukan penghapusan sehingga sanski tersebut tidak dianggap sebagai bentuk pelanggaran Hak Asasi Manusia (HAM). Sanksi ini sebelumnya sudah pernah diterapkan di desa adat pedawa namun karena permasalahan yang dialami oleh desa adat pada saat itu sudah bisa diatasi serta tidak munculnya permasalahan yang sama di beberapa tahun berikutnya maka sanksi nunda tetegenan sudah tidak diterapkan kembali. Sanksi nunda tetegenan ini tidak melarang krama desa untuk menjalankan kewajibannya sebagai umat beragama untuk melaksanakan persembahyangan atau melaksanakan kegiatan yadnya lainnya, melainkan menunda hak krama untuk memperoleh saksi adat dalam upacara yadnya, menunda negen kena-kenaan banten piodalan namun masih bisa mengaturkan banten lainnya (bukan jenis banten piodalan), menunda hak untuk memperoleh layanan dari Desa Adat seperti dalam mengurus surat pengantar, dan lain-lain.

“....Kembali lagi hingga bertemu kegiatan rapat bungan taunnike kami menjadikan permasalahan tersebut sebagai agenda utama dalam rapat yang seharusnya hanya berlangsung sehari dua hari niki hingga lima hari, kami memang benar-benar harus sigap dalam mengambil keputusan untuk kembali menerapkan sanski kuno Desa Adat Pedawa yang memang dahulu ada. Sanksi tersebut dikenal dengan nunda tetegenan. Nunda artinya menunda dan tetegenan artinya tanggung jawab yang dipikul.Jadi nunda tetegenan merupakan penundaan dalam memperoleh hak untuk ikut memikul tanggung jawab sosial sebagai umat beragama.Jadi tidak main-main jika sanksi ini kita putuskan untuk diterapkan kembali. Sanksi nunda tetegenan niki tidak melarang krama desa untuk menjalankan kewajibannya sebagai umat beragama untuk melaksanakan persembahyangan atau melaksanakan kegiatan yadnya lainnya, melainkan menunda hak krama untuk memperoleh saksi adat dalam upacara yadnya, menundanegen kena-kenaan banten piodalan namun masih bisa mengaturkan banten lainnya (bukan jenis banten piodalan), menunda hak untuk memperoleh layanan dari Desa Adat seperti dalam mengurus surat pengantar, dan lain-lain. Sanksi nunda tetegenan niki sampun ada sejak dulu, sudah pernah diterapkan dan sudah menunjukan bahwa sanksi niki efektif untuk diterapkan, karena tidak munculnya permasalahan sejenis yang dihadapi oleh desa adat pada saat itu maka sanksi nunda tetegenan disepakati untuk tidak diterapkan kembali. Sanksi niki sudah lama nike diterapkan sekitar tahun 90 -an maka dari itu disebut dengan sanksi kune yang kembali diterapkan pada saat ini."

Penurunan angka permasalahan NPL ini menandakan bahwa manajemen LPD beserta prajuru desa adat Pedawa mampu menjalankan strategi dalam upaya menekan NPL.Sanksi nunda tetegenan yang 
merupakan budaya kuno yang dimiliki oleh Desa Adat Pedawa sebagai salah satu Desa Bali Aga yang kembali diterapkan ini dapat dikatakan efektif dalam upaya menekan NPL.

\section{Simpulan dan Saran Simpulan}

Dari penelitian yang telah dilakukan oleh peneliti, maka dapat ditarik kesimpulan yang menjawab permasalahan yang diangkat dalam penelitian ini, yaitu: LPD Desa Adat Pedawa hingga saat ini masih menggunakan awig-awig sebagai dasar dalam menjalankan kegiatan operasionalnya. Pemanfaatan awigawig pada LPD Desa Adat Pedawa bertujuan untuk meningkatkan kualitas pengendalian internal sebagai salah satu upaya untuk menekan angka NPL. Prosedur pengajuan pinjaman pada LPD Desa Adat Pedawa di dalam awig-awig sedikit mengalami perubahan terkait dengan syarat bagi krama desa yang akan mengajukan pinjaman. Pengajuan kredit yang telah disepakati hingga kini juga sesuai dengan prosedur yang benar. Namun, pada tahun 2015 LPD Desa Adat Pedawa mengalami permasalahan NPL yang cukup tinggi.

Pada pelaksanaan rapat bungan taun yang rutin dilaksanakan pada setiap tahunnya menghasilkan keputusan untuk memberikan sanksi berupa pembebanan bunga tambahan bagi krama desa yang tidak memiliki kemampuan untuk melunasi hutangnya setelah memperoleh surat peringatan ke-3, keputusan ini dimaksudkan agar krama tersebut berusaha untuk segera melunasi hutangnya. Keputusan untuk menerapkan sanksi berupa pembebanan bunga nyatanya tidak membawa perubahan angka NPL, keadaan tersebut mendorong manajemen LPD harus meminjam dana dari Bank demi keberlanjutan LPD Desa Adat Pedawa kedepannya. Pada akhir tahun 2017, prajuru desa adat (pengurus desa adat) Pedawa kembali melaksanakan rapat bungan taun untuk menerapkan strategi dalam menekan NPL.Strategi tersebut dahulu dikenal dengan istilah nunda tetegenan. Nunda artinya menunda dan tetegenan artinya tanggung jawab yang dipikul. Jadi nunda tetegenan merupakan penundaan dalam memperoleh hak untuk ikut memikul tanggung jawab sosial sebagai umat beragama. Nunda tetegenan terdiri dari 3 tingkat yaitu sanksi sosial, sanksi adat, dan sanksi saksi. Sanksi nunda tetegenan dilaksanakan kembali setelah adanya pertimbangan hingga diperoleh kesepakatan dari semua pihak karena hanya berupa penundaan bukan penghapusan sehingga sanski tersebut tidak dianggap sebagai bentuk pelanggaran Hak Asasi Manusia (HAM). Penurunan angka permasalahan NPL ini menandakan bahwa manajemen LPD beserta prajuru desa adat Pedawa mampu menjalankan strategi dalam upaya menekan NPL. Sanksi nunda tetegenan yang kembali diterapkan ini dapat dikatakan efektif dalam upaya menekan NPL.

\section{Saran}

Berdasarkan hasil observasi dan wawancara yang telah dilakukan peneliti terdapat beberapa permasalahan yang terjadi, sehingga berdasarkan permasalahan tersebut peneliti dapat memberikan saran kepada peneliti selanjutnya. Adapun beberapa saran yang perlu diperhatikan bagi penelitian selanjutnya yang tertarik meneliti tentang strategi LPD dalam upaya menekan permasalahan NPL adalah: Peniliti selanjutnya diharapkan untuk mengkaji lebih banyak sumber maupun refrensi yang terkait dengan strategi dalam menekan NPL karena dalam penelitian ini masih terdapat kekurangan.

Peneliti selanjutnya diharapkan lebih mempersiapkan diri dalam proses pengambilan dan pengumpulan data dengan menggunakan metode kualitatif ini, peneliti dapat mengeksplorasi perasaan narasumber dalam mengungkapkan perasaan secara leluasa sehingga peneliti dapat memperoleh jawaban sesuai dengan yang diharapkan khususnya terkait dengan strategi manajemen.

\section{Daftar Rujukan}

Angga Bayu. (2015). Penyelesaian Kredit Macet Pada Lembaga Perkreditan Desa Di Bali. Skripsi. Fakultas Ekonomi, Universitas Airlangga.

Data Kabupaten Buleleng.2019 "Kondisi LPD di Kabupaten Buleleng tahun 2019". Diakses di https://bulelengkab.go.id (diaksespadatanggl 1 Februari 2020).

Data Kredit Macet Kecamatan Buleleng. (2019). "Data Kecamatan di Kabupaten Buleleng yang Mengalami Kredit Macet2019".Diakses di https://bulelengkec.go.id(diakses pada 2 Februari).

Harsono, (2010: 169). Metode Analisis Data Kualitatif. Bandung : Alfabeta.

Iramanmi. (2015). Pengertian Non Performing Loan .Diakses di http://akuntansikredit NPL materi.html . (Diakses pada tanggal 7 Maret 2020).

Ismail. 2010. Pengertian Akuntansi. Diakses di http://materi akuntansi pengertian.html. (diakses pada tanggal 7 Maret 2020)

Jurnalid. (2015). Fungsi dan Tujuan Pokok Kredit. Diakses di http://jurnal.id.com/2015/11/fungsi-tujuanpokok-kredit. (diakses pada 1 januari 2020). 
Krisni Utari. (2016). Pemanfaatan Awig-Awig Untuk Meningkatkan Kualitas Sistem Pengendalian Internal Dalam Upaya Menekan Tingkat Kredit Macet Pada LPD Desa Adat Panji.Skripsi (tidak diterbitkan). Fakultas Ekonomi, Universitas Pendidikan Ganesha.

Moleong, L.J. (2011). Metodologi Penelitian Kualitatif Edisi Revisi. Bandung : PT. Remaja Rosdakarya.

Narita Dwi.(2015). "Manajemen Risiko Kredit Pada Lembaga Perkreditan Desa (LPD) Desa Lebu Sidemen, Karangasem Tahun 2015”.Volume 5, No.1.Tersediapadahttps://ejournal.undiksha.ac.id/ (diaksestanggal 31 Januari 2020).

Parlan.(2014). "Pegaruh Tingkat Rasio Kredit, Kualitas Kredit Terhadap Krisis Kredit”.Tersediapadahttp://artikel unair 2014.html. (diakses tanggal 1 Maret 2020)

Peraturan Provinsi Bali. (2007). Peraturan Daerah Nomor 3 Tahun 2007 tentang Lembaga Perkreditan Rakyat Provinsi Bali. Diakses di https://jdih.baliprov.go.id/produk-hukum/peraturan/24744.

Putri Suastini Eka. (2017)."Analisis Penerapan Sanksi Sekala (Nyata) Terhadap Evaluasi Keberhasilan Pengendalian Kredit Macet Pada Lembaga Perkreditan Desa (Studi Pada Lpd Desa Sudaji)."Tersedia padahttps://ejournal.undiksha.ac.id/ (diaksestanggal 31 Januari 2020).

Rima Ayu. (2017). Pengertian Akuntansi Kredit. Diakses di http://materi akuntansi kredit.html.(Diakses pada tanggal 27 Februari 2020).

Revi I Made. (2015). "Analisis Faktor-Faktor Penyebab Terjadinya Kredit Macet Pada Lembaga Perkreditan Desa (Lpd) Di KabupatenBuleleng"Tersediapadahttps://ejournal.undiksha.ac.id/ (diaksestanggal 2 Februari 2020).

Sarjanaku. (2012). Pengertian Kredit dan Fungsi Kredit.Diakses di http://www.sarjanaku.com/2012/12/pengertian-kredit-fungsi-unsur-macam.html pada 1 januari $\underline{2020}$.

Sudiyatno dan Surosi. (2010). Produtive Loan Theory.Diakses di http://teori-likuiditas.html. (Diakses pada 1 April 2020).

Sudiyani Nyoman. (2016). "Fungsi Sistem Pengendalian Intern Dalam Mencegah Kredit Macet Pada LPD (Studi Kasus Pada LPD Pakraman Bitera Kabupaten Gianyar)". Tersediapadahttps://ejournal.universitasngurahrai.ac.id/ (diaksestanggal 7 Maret 2020).

Sugiono. (2017). Metode Penelitian Kuantitatif,Kualitatif, dan R\&D. Bandung : Alfabeta.

Sutarno.(2012). Aspek-Aspek Hukum Perkreditan Pada Bank.Bandung: Alfabeta 2009.

Trianto.(2011). Metode Penelitian Kualitatif.Bandung : Alfabeta. 